\title{
NUTRITIVE ADVANTAGES OF GOAT MILK AND POSSIBILITIES OF ITS PRODUCTION IN REPUBLIC OF MACEDONIA
}

\author{
Nikola Pacinovski ${ }^{1}$, Gordana Dimitrovska ${ }^{2}$, Ljupčo Kočoski ${ }^{2}$, Goce Cilev $^{3}$, \\ Mirjana Menkovska ${ }^{1}$, Biljana Petrovska $^{3}$, Apostol Pacinovski ${ }^{4}$ \\ ${ }^{1}$ Ss. Cyril and Methodius" University in Skopje, Institute of Animal Science, \\ Blvd. Ilinden 92A, 1000 Skopje, Republic of Macedonia \\ ${ }^{2}$ St. Kliment Ohridski University, Faculty of Biotechnical Sciences, \\ Str. Partizanska bb, 7000, Bitola, Republic of Macedonia, \\ ${ }^{3}$ St. Kliment Ohridski University, Veterinary Faculty, \\ Str. Prilepska bb, 7000, Bitola, Republic of Macedonia \\ ${ }^{4}$ Taurus Farms, Str. M. Tito, bb, Bogdanci, Republic of Macedonia \\ npacinovski@yahoo.com
}

\begin{abstract}
With certain exceptions, goat milk is similar to sheep and cow milk and, particularly, to human milk in respect to its composition, biological traits and nutritive value. In relation to some parameters goat milk has more advantages than the milk of other species. Due to its specific composition, milk is used in the production of variety of cheese and different types of milk drinks. In some countries of western Europe are produces reputable types of goat cheese which reach significantly higher price than the cheeses from cow milk. The people from Mediterranean and Middle Eastern countries, have a tradition for regular usage of drinks made of fresh or processed goat milk in people's diet. Due to the goat's ability to transform carotene into vitamin A, the fat in goat milk has exceptionally white color. Goat milk fat drops are smaller and more evenly distributed in the milk, allowing faster and easier digestion in human organisms. This is the reason why people with digestive problems prefer consuming goat milk. Fat in goat milk contains large amount of caprylic and caproic acids. According to the literature data a few of these acids are in free form, contributing to the specific odour and flavor of goat milk. Many researches characterize goat milk as a drink for convalescent but also as basic detoxifier of human organism. This work attempts to describe the actual situation of goat breeding in Macedonia, nutritive value of goat milk and the advantage in relation to the milk of other animal species and human milk.
\end{abstract}

Key words: goat milk; cow milk; sheep milk; human milk; nutritive value; detoxifier

\section{ХРАНЛИВИ ПРЕДНОСТИ НА КОЗЈОТО МЛЕКО И МОЖНОСТИ ЗА НЕГОВО ПРОИЗВОДСТВО ВО РЕПУЛИКА МАКЕДОНИЈА}

Со одредени исклучоци, козјото млеко во однос на неговиот состав, биолошките својства и хранливата вредност е слично на овчото и кравјото млеко, а особено на млекото од хуманата популација. Во однос на некои параметри козјото млеко има и одредени предности во однос на другите видови на млеко. Поради својот специфичен состав, ова млеко се користи за производство на различни сирења и повеќе видови млечни пијалаци. Во некои земји на Западна Европа се произведуваат познати видови козји сирења кои достигнуваат значително повисоки цени во споредба со сирењата од кравјото млеко. Луѓето во земјите од Медитеранот и Блискиот Исток во својата исхрана имаат традиција за редовна употреба на пијалаци произведени од свежо или преработено козјо млеко. Поради способноста на козата да го трансформира каротинот во витамин А, мастите во козјото млеко имаат исклучително бела боја. Масните капки во козјото млеко се помали и рамномерно распоредени, поради што побрзо и полесно се варат во човечкиот организам. Поради тоа, луѓето со дигестивни проблеми претпочитаат консумирање на козјото млеко. Мастите во козјото млеко содржат голема количина каприлна и капронска киселина. Според податоци од литературата, неколку од овие киселини се во слободна форма, со што придонесуваат за специфичниот мирис и вкус на козјото млеко. Многу истражувања го карактеризираат козјото млеко не само како пијалак за опоравување, туку и како основен детоксикатор на човечкиот организам. Трудот има за цел да ја опише актуелната состојба на козарството во Македонија, 
хранливата вредност на козјото млеко, како и неговите предности во однос на млекото од други животински видови и човечкото млеко.

Клучни зборови: козјо млеко; кравјо млеко; овчо млеко; човечко млеко; хранлива вредност; детоксикатор

\section{INTRODUCTION}

Milk from goats accounted for 2.4 percent of global milk production in 2010 (FAOSTAT, 2012). India is the main producer of goat milk (30 percent), followed by Bangladesh (17 percent) and Sudan (11 percent) (Wijesinha-Bettoni and Burlingame, 2013). Home consumption of goat milk is reported to be very high: goats are the main suppliers of dairy and meat products for rural populations (Haenlein, 2004). Some goat breeds, such as the Bedouin goat, are able to survive under extreme environmental conditions on meagre fodder and water intake, which makes them particularly suited for surviving in regions with harsh climatic conditions. However, the goat is not just associated with underdevelopment and poverty - dairy goat farming is also significant to the economies of some Mediterranean countries (Boyazoglu et al., 2005) owing to the connoisseur interest in goat milk products such as cheeses and yoghurt (Haenlein, 2004).

Dairy goat farming is a vital part of the national economy in many countries, especially in the Mediterranean and Middle East region (Park et al., 2007). Goat breeding industry represents developed stock breeding in most of the Mediterranean countries within Europe (France, Spain, Italy, Greece and Turkey) which pays significant attention to its development and industrialization. Goat breeding is also a developed branch in other Western European countries such as Switzerland, Netherlands, Germany etc.

This livestock industry has a centuries-old tradition in Macedonia. Due to environmental factors in many regions in Macedonia, there is a type of vegetation suitable for goat breeding wherefore these animals have provided subsistence of the population in the past centuries. It is known that goats are one of the most adaptive species among the ruminants. The capacity of goats to adapt to harsh environment is related to their ability to produce low cost, high quality milk and meat on scarce and low-quality forage supply that determines the spreading of the species all over the world.

Goat ability to produce milk is way more expressive than other mammals. Namely, in a year of production, with no physical disorders, a goat can produce milk, which exceeds its live weight by a factor of 20. It is pretty picky with food, with shrubby and underbrush plants and young trees as most attractive for eating. This is the reason why in most countries in Europe and worldwide national laws for livestock allow goat grazing only under human supervision. However, capability due to the conversion of natural plant food into high quality food for humans, goat breeding is one of the cheapest and most economical livestock industries.

Goat production systems usually correspond to the climatic and economic characteristics of the regions and size of the farms. In Macedonia predominate extensive goat dairy industry and machine milking is not widespread throughout the country. There is much to be done about the improvement of goat farms in respect to goat breeding and comprehensive mechanization of farm routines which both increase efficiency of the farms.

In Macedonia, the potential for goat breeding development is reflected with the fact, the total agricultural area is 1,121,000 hectares, 611,000 of which are pastures and the rest (510,000 ha) arable land (Statistical Yearbook 2006-2010, 2011).

Here comes the fact that much of the forests with high and low trunks in an advanced stage of its development (i.e. established forests) are also potential for goat breeding development. Primarily, this is due to the fact that in such forests, goats can not cause major damage on plant vegetation.

Today in the world are bred 875.5 millions goats, represented with more than 200 breeds, of which about $63 \%$ are for milk production , $27 \%$ for meat production, and only about $5 \%$ for the production of wool (mohair). Most goats are bred in Asia (539 milions), follows Africa (276 milions), Australia and New Zealand (4.5 milions), whereas in Europe are bred 17 millions goats, of which Greece 4.85 milions, Spain 2.93 milions, France 1.43 milions, etc. (FAOSTAT, 2011).

Historically, the number of the goats, bred in Macedonia was around 500,000 heads, with the law for prohibited goat breeding (Law for Prohibited Goat Breeding, 1948). This law had highly significant negative role in reducing the number of goats in Republic of Macedonia. The stagnation of this livestock industry continues until 1989 when another law so-called Law on Goat Breeding was 
promulgated (Law on Goat Breeding, 1989). In 2012 the number of goats in Republic of Macedonia was 63,585 heads of all categories, which is 7193 heads less (around 11\%), compared with the number of goats in 2011 (MAFWE, 2013). High priorities for the development of goat breeding in the country are given in the National strategy of agriculture and rural development from 20072013, (MAFWE, 2007).

According to the Food and Veterinary Agency, Identification and Registration Unit of Livestock there are 1800 goat farms in Republic of Macedonia. There are 6 genotypes (breeds) of goats present in Macedonia in the system for identification and marking of livestock within the Food and Veterinary Agency: domestic Balkan goat, Alpine, Saanen goat, crossbreeds with Alpine, crossbreeds with Saanen goat and genotype registered under the name of other population. According the same Agency in 2011 domestic Balkan goats constitute $48 \%$ of the population whereas Alpine goats, crossbreeds with Alpine goat, Saanen goats, and crossbreeds with Saanen goats compose $5.5 \%, 7.9 \%, 7.8 \%, 3.4 \%$, respectively. The rest of population are recorded as other goat breeds, (Pacinovski et al., 2012).

The production of milk in domestic population of goat ranges from 100 to 250 liters (Kozarovski, 1998), while in Alpina goats varies depending on the country where it is bred. An average milk yield of 800 liters was recorded in Alpine goats in farm-breeding conditions, while with producers with fewer goats up to 900 liters (Mekić et al., 2005). According to other studies, in United States is determined maximal milk yield of 2,215 liters in lactation (Popovski and Stefanovska, 2002). The milk yield in Alpina breed of goat in Serbia was 752 liters for 271 days of lactation (Skalicki et al., 1998). This goat breed has high capacity for acclimatization resulting in its presence in many European and non-European countries, serving as improver in creating dairy goats of its type.

Some important factors that complicate the development of goat breeding in Republic of Macedonia are: unfavorable breed composition, small flocks, disorganized purchase of goat milk in certain regions of the country, disorganized unpremeditated purchase of goats for slaughter or goat meat, lack of labor, insufficient and irregular application of selective measures in flocks etc. However, it can be ascertain that goat breeding in Macedonia has spontaneous and continuous develop- ment compared to previous years. This is a reason for greater interest of farmers breeding goats as a branch that can provide secure subsistence and profit achievement (Kozarovski, 1998).

\section{COMPOSITION AND TRAITS OF GOAT MILK}

Goat milk is similar to cow's milk by its composition, biological and energy value. It is also similar with human milk, with certain exceptions. Even in relation to some characteristics, goat milk has some of its advantages. Also the gross composition of goat and sheep milk is similar, but sheep milk contains more fat, solids non-fat, proteins, caseins, whey-proteins and total ash as compared with goat milk. These differences make the rennet coagulation time for sheep milk shorter and the curd firmer owing to the differences in the caseins (Fraga et al., 1998). The composition of goat, cow, sheep and human milk is shown in Table 1.

In terms of chemical composition, goat milk contains higher amount of total dry matter, proteins, fat and ash than cow and human milk, but lactose content is less. On the other hand, the content of all these parameters is higher in sheep milk compared with goat milk. The content of some minerals $(\mathrm{Ca}, \mathrm{P}, \mathrm{K}, \mathrm{Zn})$ is also higher in goat, compared with cow and human milk, but not in comparison with sheep milk, while content of K, $\mathrm{Mg}$ and $\mathrm{Na}$ is higher in goat, compared with cow, sheep and human milk. Also goat milk contains higher amount of vitamin $\mathrm{B}_{2}$ and vitamin $\mathrm{B}_{3}$ than cow and human milk (Table 1). Higher content of $\mathrm{Ca}, \mathrm{Mg}$ and $\mathrm{P}$ in goat milk than cow and human milk found Arora et al., (2013).

Due to its specific composition goat milk is used for manufacture of different type of cheese and other milk products. Western European countries produce reputable types of goat cheese which can reach significantly higher price than cow's cheese. Mediterranean and Middle Eastern countries have a tradition for regular usage of drinks made of fresh or processed goat milk in people's diet.

Owing to the ability of goat to transform carotene into vitamin A, the fat in goat milk has exceptionally white color. Goat milk fat drops are smaller and more evenly distributed, allowing faster and easier digestion in human digestive tract. Goat milk, but also horse, donkey, camel and human milk form soft curds in the stomach, which are more easy to digest and are physiologically 
more apt for infant nutrition (Claeys et al., 2014). This is the reason why people with digestive problems need to prefer consuming goat milk. Fat in goat milk contains large amount of caprylic and caproic acids. According to literature data a few of these acids are in free form, contributing specific odour and flavor of goat milk.

Table 1

Chemical, mineral and vitamin content of goat, cow, sheep and human milk

\begin{tabular}{|c|c|c|c|c|}
\hline Constituent & Goat milk & Cow milk & Sheep milk & Human milk \\
\hline Total dry matter $(\mathrm{g} / \mathrm{l})$ & $119-163$ & $118-130$ & $181-200$ & $107-129$ \\
\hline Proteins $(\mathrm{g} / \mathrm{l})$ & $30-52$ & $30-39$ & $45-70$ & 9-19 \\
\hline Fat $(g / l)$ & $30-72$ & $33-54$ & $50-90$ & $21-40$ \\
\hline Lactose (g/l) & $32-50$ & $44-56$ & $41-59$ & $63-70$ \\
\hline Ash (g/l) & $7-9$ & $7-8$ & $8-10$ & $2-3$ \\
\hline Casein / whey ratio & 3.5 & 4.7 & 3.1 & $0.4-0.5$ \\
\hline Energy (kJ/l) & $2802-2894$ & $2709-2843$ & $4038-4439$ & 2843 \\
\hline $\mathrm{Ca}(\mathrm{mg} / 100 \mathrm{ml})$ & 85-198 & $112-123$ & $159-242$ & $28-34$ \\
\hline $\mathrm{P}(\mathrm{mg} / 100 \mathrm{ml})$ & $79-153$ & 59-119 & $124-175$ & $14-43$ \\
\hline $\mathrm{K}(\mathrm{mg} / 100 \mathrm{ml})$ & $140-242$ & $106-163$ & $94-162$ & $53-62$ \\
\hline $\mathrm{Mg}(\mathrm{mg} / 100 \mathrm{ml})$ & $10-36$ & $7-12$ & $16-25$ & $3-4$ \\
\hline $\mathrm{Na}(\mathrm{mg} / 100 \mathrm{ml})$ & $28-59$ & 58 & $30-75$ & $10-18$ \\
\hline $\mathrm{Fe},(\mathrm{mg} / 100 \mathrm{ml})$ & $0.05-0.1$ & $0.03-0.1$ & $0.08-0.1$ & $0.04-0.2$ \\
\hline $\mathrm{Zn}(\mathrm{mg} / 100 \mathrm{ml})$ & $0.4-0.6$ & $0.3-0.55$ & $0.4-0.9$ & $0.2-0.4$ \\
\hline $\mathrm{Cu}(\mathrm{mg} / 100 \mathrm{ml})$ & $0.02-0.05$ & $0.01-0.08$ & $0.03-0.05$ & $0.02-0.06$ \\
\hline Thiamin (Vit. $\left.B_{1}\right)(\mu \mathrm{g} / 100 \mathrm{ml})$ & $40-68$ & $28-90$ & $28-80$ & $14-17$ \\
\hline Riboflavin (Vit. $\left.\mathrm{B}_{2}\right)(\mu \mathrm{g} / 100 \mathrm{ml})$ & $110-210$ & $116-202$ & $160-429$ & $20-60$ \\
\hline Niacin (Vit. $\left.B_{3}\right)(\mu \mathrm{g} / 100 \mathrm{ml})$ & $187-370$ & $50-120$ & $300-500$ & $147-178$ \\
\hline Pantothenic acid (Vit. $\left.B_{5}\right)(\mu \mathrm{g} / 100 \mathrm{ml})$ & 310 & $260-490$ & $350-408$ & $184-270$ \\
\hline Pyridoxine (Vit. $\left.B_{6}\right)(\mu \mathrm{g} / 100 \mathrm{ml})$ & $7-48$ & $30-70$ & $27-80$ & $11-14$ \\
\hline Biotin $\left(\right.$ Vit. $\left.B_{7}\right)(\mu \mathrm{g} / 100 \mathrm{ml})$ & $1.5-3.9$ & $2-4$ & $0.9-9.3$ & $0.4-0.6$ \\
\hline Folic acid (Vit. $\left.\mathrm{B}_{9}\right)(\mu \mathrm{g} / 100 \mathrm{ml})$ & $0.24-1$ & $1-18$ & $0.24-5.6$ & $5.2-16$ \\
\hline Cobalamin (Vit. $\left.\mathrm{B}_{12}\right)(\mu \mathrm{g} / 100 \mathrm{ml})$ & $0.06-0.07$ & $0.27-0.7$ & $0.30-0.71$ & $0.03-0.05$ \\
\hline Ascorbic acid (Vit. C) ( $\mu \mathrm{g} / 100 \mathrm{ml})$ & $900-1500$ & $300-2300$ & $425-6000$ & $3500-10.000$ \\
\hline Vitamin A $(\mu \mathrm{g} / 100 \mathrm{ml})$ & $50-68$ & $17-50$ & $41-50$ & $30-200$ \\
\hline Chole-calciferol (Vit. $\left.D_{3}\right)(\mu \mathrm{g} / 100 \mathrm{ml})$ & 0.25 & 0.3 & $0.18-1.18$ & $0.04-0.1$ \\
\hline
\end{tabular}

Source: Claeys et al. (2014)

The presence of proteins in milk serum in goat milk is also slightly higher compared to cow's milk owing to the greater amount of globulins in goat milk. Goat milk casein shows particular specificities in dissolution allowing it to be different from cow's milk. Due to the presence of antibod- ies, i.e. immunological traits of milk itself, goat milk has expressive bactericidal traits.

Goat milk has a high casein and $\mathrm{Ca}$ content compared to human milk (Barlowska et al., 2011). Also lipids in goat milk have higher physical characteristics than in cow milk, but there are varia- 
tions between different reports (Anifantakis, 1986; Park, 2006).

Among domestic animals, the goats are resistant to many diseases, especially tuberculosis which is based on a system expressed on immune bodies. Due to the high calcium content, consumption of fresh, unprocessed goat milk is recommended for people suffering tuberculosis. This method of treatment is applied in certain regions where there are no effective means of treatment. Goats have many unique differences in anatomy, physiology and product biochemistry from sheep and cattle, which support the contention of many unique qualities of dairy goat products for human diet (Haenlein, 2004).

Also, goat milk differs from cow or human milk in having better digestibility, alkalinity, buffering capacity, and certain therapeutic values in medicine and human nutrition (Haenlein and Caccese, 1984; Park and Chukwu, 1989; Park, 1994).

One of the main observations for consuming goat milk and dairy products manufactured without prior heat treatment is the possibility to transfer the brucellosis agent and other diseases due to poor hygiene conditions in production and non-performed pasteurization. In order to overcome this and other unwanted effects, heat treatment of milk is recommended in order to destroy pathogens and harmful microflora.

\section{Physical traits of goat milk}

The physical characteristics such as moisture, total solids, specific gravity, $\mathrm{pH}$, conductivity, viscosity and titratable acidity are important parameters in studying the physicochemical compositions and nutritional aspects of milk.

The specific gravity (density) of goat and cow's milk is quite similar. It ranges from 1.03 to 1.04. The viscosity of goat milk is 1.44 , which is higher than that of cow milk (1.38), while the value of conductivity at goat milk is also higher (10.8) than that of cow milk (9.20), (Table 2).

Titratable acidity shown as percentage of lactic acid is 1.35 at goat milk, whose value is lower than titratable acidity of cow's milk (1.44). An average $\mathrm{pH}$ value in goat milk is 6.59 , while in cow's milk 6.76, (Table 2).

Almost identical results in terms of the specific gravity (1.029) and $\mathrm{pH}$ value (6.50-6.80), note Park et al. (2007) and Sabahelkhier et al. (2012), while the Park et al. (2007) found slightly higher values for viscosity of goat milk (2.12).
Table 2 .

\section{Physical characteristics of goat and cow milk}

\begin{tabular}{lll}
\hline \hline Constituent & Goat milk & Cow milk \\
\hline Moisture (\%) & $80.5 \pm 4.66$ & $86.8 \pm 5.02$ \\
Total solids (\%) & $12.9 \pm 1.01$ & $13.5 \pm 1.22$ \\
Specific gravity & $1.03 \pm 0.02$ & $1.04 \pm 0.05$ \\
$\mathrm{pH}$ & $6.59 \pm 0.59$ & $6.76 \pm 0.51$ \\
Conductivity (mS) & $10.8 \pm 2.07$ & $9.20 \pm 1.95$ \\
Viscosity (cP) & $1.44 \pm 0.53$ & $1.38 \pm 0.41$ \\
Titratable acidity (\% lactic acid) & $1.35 \pm 0.38$ & $1.44 \pm 0.40$ \\
\hline
\end{tabular}

Source: Imran et al. (2008)

\section{PRODUCTION OF QUALITY AND HYGIENIC GOAT MILK}

The chemical composition of goat milk is an important factor that affects further quality and profit of products made from it. On the other hand, the milk should be hygienic and healthy with the lowest number of microorganisms. The main sources of microbial contamination of goat milk are: udder, skin and hair of the animals, hygienic milker, insects, air, water, milking containers, and milking blanket. Great attention needs to be paid to all these factors in order to produce milk as a quality raw material for further processing from which depends the quality of the final product such as: cheese, yogurt, curds etc. In many European countries milk, including goat milk, is paid according to the number of microorganisms in it and supplemented by the chemical composition or the content of milk fat and protein.

In order to improve the quality of goat milk special attention should be given to the following:

- Milking and filtering hygiene;

- Separation of milk produced by animals suffering from mastitis and treated with antibiotics;

- Personal hygiene and regular washing and disinfection of milking equipment;

- Storage of the milk till processing with cooling or with cold water;

- Titratable acidity of the goat milk should range from 14 to $18 \mathrm{~T}$, while $\mathrm{pH}$ from 6.5 to 6.8 ;

- Elimination of milk with added water and other means of falsification.

All these factors are very important for producing hygienic milk, therefore the same should be given great attention. 
Herewith goes the Law on Quality of Agricultural Products (Law on Quality of Agricultural Products, 2010), according to which in our country milk should be paid according to its quality, protein and fat content, somatic cells number and number of microorganisms (Article 126 in the same law). This method of operation of dairy plants and purchase centers is unavoidable if we take in consideration that almost all activities in the field of agriculture in Macedonia are controlled by the Agricultural Committee in EU, and Macedonia as EU member candidate has obligation to adopt an enact all these laws.

\section{HEALING TRAITS OF GOAT MILK}

Goat milk is very important food for children and adults (convalescents) with significantly better bio-availability compared to cow's milk. Children who consume goat milk manifest significant improvement in relation to many aspects of health and physical condition such as: improved body weighs, bone strength, higher growth rate, skeleton mineralization, vitamin A concentration in blood serum, thiamin, calcium, riboflavin, hemoglobin and increased concentration of niacin in the blood. Iron content of goat milk is greater than in cow and breast milk.

The importance of goat milk in children's diet is known since ancient times. In developed countries like USA and South Africa, goat milk is bottled specially for young children. Children can overcome allergic problems with consumption of goat milk instead of cow's milk. This is another evidence of healing traits of goat milk. Goat milk and its products such as yoghurt, cheese and powder have three-fold significance in human nutrition: (1) feeding more starving and malnourished people in the developing world than from cow milk; (2) treating people afflicted with cow milk allergies and gastro-intestinal disorders, which is a significant segment in many populations of developed countries and (3) filling the gastronomic needs of connoisseur consumers, which is a growing market share in many developed countries (Haenlein, 2004).

Renneting time for goat milk is shorter than for cow milk and the weak consistency of the gel is beneficial for human digestion but decreases its cheese yield. Goat milk also have simple lipids (diacylglycerols, monoacylglycerols, cholesterol esters), complex lipids (phospholipids) and liposoluble compounds (sterols, cholesterol esters, hy- drocarbons). Also non-protein nitrogen (NPN) contents of goat milk is higher than in cow milk (Jooyandeh and Aberoumand, 2010).

Gastrointestinal disorders, vomiting, colic, diarrhea, constipation, and respiratory problems can be alleviated if goat milk is included in diet. It is proven that fermented goat milk products are ideal food for people allergic to cow's milk. Goat milk is naturally homogenized. Its consumption helps improve slow digestion and absorption. Regular consumption of goat milk significantly improves weight and skeleton mineralization and also increases the level of vitamins, minerals and hemoglobin in blood serum. All these traits are significant advantage compared to human milk.

Other healing or medicinal traits of goat milk are: content of appropriate concentration of triglycerides, which pay important role in protecting human body from many diseases such as: malabsorption syndrome - abnormality in nutrients absorption, steatorrhoea - excess of fat in the feces, chyluria, hyperlipoproteinaemia, cystic fibrosis, gallstone, pediatric epilepsy etc. Triglycerides minimize the sedimentation of cholesterol in arteries, help with gallstone and cholesterol dissolution and significantly contribute to normal growth and development of children. Goat milk has an extremely suitable composition of fatty acids (Banskalieva, 2001). People (adults and children) suffering from eczema, asthma, chronic cold, migraine, colitis (inflammation of the large intestine including all three parts: colon, caecum and rectum), allergy to bee pollen, peptic ulcer, epigastric distress and pain in abdomen due to an allergic reaction from cow's milk or milk substitutes, should increase consumption of goat milk because of its less allergic nature and the impact on all gastro-pathological conditions.

The physiological and biochemical facts of the unique qualities of goat milk are just barely known and little exploited, especially not the high levels in goat milk of short and medium chain fatty acids, which have recognized medical values for many disorders and diseases of people (Haenlein, 2004).

The products made of goat milk have similar traits and there are no reactions even by most sensitive persons. Children who suffer from allergies (with eosinophilia) related to gastrointestinal tract also showed improvements after the consumption of goat milk. Several data show that there are children who suffer from chronic entropathy due to consumption of cow's milk, but the situation im- 
proves after including goat milk in the diet. All this suggests that goat milk has wide range of healing traits which confirm benefit of including lager quantity in the people diet.

\section{CONCLUSION}

Republic of Macedonia has appropriate conditions for goat breeding development with plenty of pastures, especially forests with low and high trunks which are ideal place for goat breeding, considering the fact that this animal enjoys browsing.

The capacity for breeding goats in Republic of Macedonia is quite greater than the current situation where the goat population constitutes less than 70000 goats. Here should be followed the experience of developed countries like France, Spain, Italy and Greece, where goat breeding industry is given special attention and where the consumption of goat milk and products made of goat milk is quite big. In order to obtain quality products of goat milk and cheese, great attention should be paid to the quality of the raw milk, including animal diet, hygiene, animal state of health.

All these factors are important in order to produce quality milk with higher price. One of the solution for significant improvement of goat milk quality is introducing of machine milking, which already in use in some farms in Macedonia. Although, some dairy plants already purchase goat milk for producing dairy products, the advantage of their use in human's diets should be further elucidate. The presence of goat milk in human's diet should be a routine due to its numerous healing traits.

\section{REFERENCES}

[1] Anifantakis, E. M.: Comparison of the physico-chemical properties of ewe's and cow's milk. In: International Dairy Federation (Ed.), Proceedings of the IDF Seminar Production and Utilization of Ewe's and Goat's Milk, Bulletin No. 202. Athens, Greece, pp. 42-53 (1986).

[2] Arora, R., Bhojak, N., Joshi, R.: Comparative Aspects of Goat and Cow Milk. International Journal of Engineering Science Invention. 2, 1. pp. 7-10 (2013). www. ijesi.org.

[3] Banskalieva, V.: Fatty acid composition of milk fat triacylglycerols in three breeds of goat during lactation. Bulgarian Academy of Sciences. Biologie, Tome 54, No 9. (2001).

[4] Bar1owska, J., Szwajowska, M., Litwinczuk, Z., Król, J. Nutritional value and technological suitability of milk from various animal species used for dairy production. Comprehensive Reviews in Food Science and Food Safety, 10, 291-302 (2011).

[5] Boyazoglu, J., Hatziminaoglou, I., Morand-Fehr, P.: The role of the goat in society: Past, present and perspectives for the future. Small Ruminant Res., 60 (1-2 special. issue): 13-23 (2005).

[6] Claeys, L. W., Verraes, C., Cardoen, S., De Block, J., Huyghebaert, A., Raes, K., Dewettinck, K., Herman, L.: Consumption of raw or heated milk from different species: An evaluation of the nutritional and potential health benefits. Food Control 42, 188-201:(2014).

[7] FAOSTAT. (2011). Annual report.

[8] FAOSTAT. (2012). Annual report.

[9] Fraga, M. J., Fontecha, J., Lozada, L., Juarez, M.:. Silver ion adsorption thin layer chromatography in the study of the composition of milk fat triglycerides. J. Agric. Food Chem. 46:1836-1843 (1998).

[10] Haenlein, G. F. W., Caccese, R.: Goat milk versus cow milk. In: Haenlein, G. F. W., Ace, D. L. (Eds.), Extension Goat Handbook. USDA Publ., Washington, DC, p. 1, E$1,1984$.

[11] Haenlein, W. F. G.: Goat milk in human nutrition. Small Ruminant Research, Vol. 51, Issue 2, p-p. 155-163 (2004).

[12] Imran, M., Khan, H., Hassan, S. S., Khan, R.: Physicochemical characteristics of various milk samples available in Pakistan. J. Zhejiang. Univ. Sci. 9 (7), 546-551 (B 2008).

[13] Jooyandeh, H., Aberoumand, A.: Physico-chemical, nutritional, heat treatment effects and dairy products aspects of goat and sheep milks. World Applied Sciences Journal 11 (11), 1316-1322 (2010).

[14] Kozarovski, N.: Goat Breeding and Sheep Breeding. University “St. Kliment Ohridski”, Bitola, pp. 1-147. (1998).

[15] Law for Prohibited Goat Breeding: Gazette of NRM, No. 38/48 (1948).

[16] Law on Goat Breeding: Gazette of Republic of Macedonia, No. 21 (1989).

[17] Law on Quality of Agricultural Products: Gazette of Republic of Macedonia, No. 140 (2010).

[18] MAFWE: National strategy of agriculture and rural development from 2007-2013, p. 1-162. Ministry of Agriculture, Forestry and Water Economy od Republic of Macedonia, 2007.

[19] MAFWE: Annual report of Agriculture and Rural Development 2012. Skopje, p-p. 1-131, 2013.

[20] Mekić, C., Krajinović, M, Zujović, M.: Development of intensive goat production. Symposium of Milk Production and Processing. Work Collection, Belgrade, pp. 9-17, 2005.

[21] Pacinovski, N., Dojčinovski, T., Petrovska, S., Kočoski Lj., Kozarovski, N., Dumova-Jovanoska, E.: A survey of forming regional reprocentre of sheep and goats in east region. My Ground, Ohrid, pp. 1-272, 2012.

[22] Park, Y. W., Chukwu, H. I.: Trace mineral concentrations in goat milk from French-Alpine and Anglo-Nubian breeds during the first 5 months of lactation. J. Food Compos. Anal. 2, 161-169 (1989). 
[23[ Park, Y. W.: Hypo-allergenic and therapeutic significance of goat milk. Small Rumin. Res. 14, 151-161 (1994).

[24] Park, Y. W.: Goat milk - chemistry and nutrition. In: Park, Y. W., Haenlein, G. F. W. (Eds.), Handbook of Milk of Non-bovine Mammals. Blackwell Publishing Professional, Oxford, UK/Ames, Iowa, pp. 34-58, 2006.

[25] Park, Y. W., Juarez, M., Ramos, M., Haenlein, W. F. G.: Physico-chemical characteristics of goat and sheep milk. Small Ruminant Research, 68, 88-113 (2007).

[26] Popovski, K., Stefanovska, J.: Goat breeding, Vita-Vet. Skopje, pp. 1-105, 2002.

[27] Sabahelkhier, M. K., Faten, M. M., Omer, F. I.:. Comparative determination of biochemical constituents betwe- en animals (goat, sheep, cow and camel) milk with human milk. Res. J. Recent Sci., 1 (5), 69-71 (2012).

[28] Skalicki, Z., Urošević, M., Ostojić, M., Mekić, C.: Milk production of French Alpine goat. Journal for Scientific Agricultural Research, 59 (1-2), 208, pp. 17-22 (1998). Belgrade.

[29] State Statistical Office of the Republic of Masedonia: Statistic Yearbook 2006-2010, 2011.

[30] Wijesinha-Bettoni, R., Burlingame, B.: Milk and dairy product composition. Milk and Dairy products in human nutrition. FAO, Rome, Italy, 2013. 